\title{
PEMANFATAN EKSTRAK BIJI TERATAI SEBAGAI BAHAN AKTIF ANTIBAKTERI UNTUK PEMBUATAN HAND SANITIZER
}

\author{
Farindya Dwi Cahyaningtyas ${ }^{1 *}$, Zhilla Afifatul Ukrima ${ }^{1}$, Nora $^{1}$, Amaria $^{1}$ \\ ${ }^{1}$ Jurusan Kimia, Universitas Negeri Surabaya, Jalan Ketintang, Surabaya, 60231 \\ * Author Utama, email: farindyacahyaningtyas16030234022@mhs.unesa.ac.id \\ Co-author 1, email: zhillaukrima16030194027@mhs.unesa.ac.id \\ Co-author 2, email: nora.18017@mhs.unesa.ac.id \\ Co-author 3, email: amaria@unesa.ac.id
}

\begin{abstract}
Lotus seeds contain phytochemical components such as alkaloids, flavonoids, steroids, glycosides, saponins, tannins, and triterpenoids. The phytochemical component found in lotus seeds can be used as an antibacterial compound. This study aims to determine the antibacterial activity of gel hand sanitizer extract of ethyl acetate of lotus seeds. This research begins with lotus seeds extracted by maceration using ethyl acetate. Maseration is done for 3 days. The macerate produced is then evaporated with a rotatory evaporator and the etyl asetat content is removed by using a waterbath by keeping the temperature $<60^{\circ} \mathrm{C}$. Then the gel preparation process is carried out. The gel preparations were then tested for the antibacterial activity of the preparations in Escherichia coli and Staphylococcus aureus, the stability test of gel hand sanitizer preparations consisting of $\mathrm{pH}$ test, scattering power test, and syneresis test. As well as organoleptic tests include color, smell, and shape. The results showed that the more lotus seed extract was added, the more dark the color produced, the stronger the aroma, the less thick the shape, and the wider the spread of power. $\mathrm{pH}$ formula from F1, F2, F3, respectively, 6.4; 5.9; 5.1. The gel hand sanitizer preparation is not synheresis. Antibacterial activity of hand sanitizer lotus seed extract which can inhibit or kill bacteria very well at a concentration of $1.5 \%$ which results in a $12 \mathrm{~mm}$ inhibition zone in Staphylococcus aureus and $10 \mathrm{~mm}$ in Escherichia coli.
\end{abstract}

Keywords: Lotus, hand sanitizer, and antibacterial..

\section{ABSTRAK}

Biji teratai memiliki kandungan komponen fitokimia seperti alkaloid, flavonoid, steroid, glikosida, saponin, tannin, dan triterpenoid. alkaloid, flavonoid, steroid, glikosida, saponin, tannin, dan triterpenoid yang terdapat pada biji teratai seperti flavonoid, alkaloid, tannin, dapat digunakan sebagai senyawa antibakteri. Penelitian ini bertujuan mengetahui aktivitas antibakteri gel hand sanitizer ekstrak etil asetat biji teratai. Penelitian diawali dengan ekstraksi biji teratai kering dengan cara maserasi selama 3 hari menggunakan etil asetat. Maserat yang dihasilkan selanjutnya dievaporasi menggunakan rotatory evaporator dan kandungan pelarut etil asetat dihilangkan dengan menggunakan waterbath dengan menjaga suhunya $<60^{\circ} \mathrm{C}$. Selanjutnya dilakukan proses pembuatan sediaan gel. Sediaan gel yang dihasilkan kemudian dilakukan pengujian aktivitas antibakteri sediaan pada Escherichia coli dan Staphylococcus aureus uji stabilitas sediaan gel hand sanitizer yang terdiri dari uji $\mathrm{pH}$, uji daya sebar, uji sineresis, serta uji organoleptis meliputi warna, bau, dan bentuk. Hasil penelitian menunjukkan bahwa semakin banyak ekstrak biji teratai yang ditambahkan, warna yang dihasilkan semakin gelap, aroma yang semakin kuat, bentuk yang tidak kental, serta daya sebar yang semakin lebar. $\mathrm{pH}$ formula dari F1, F2, F3 berturut-turut yaitu 6,$4 ; 5,9 ; 5,1$. Sediaan gel hand sanitizer tidak sineresis. Aktivitas antibakteri hand sanitizer ekstrak biji teratai yang dapat menghambat atau mematikan bakteri dengan sangat baik pada konsentrasi $1,5 \%$ yang menghasilkan zona hambat sebesar $12 \mathrm{~mm}$ pada bakteri Staphylococcus aureus dan $10 \mathrm{~mm}$ pada bakteri Escherichia coli.

Kata Kunci: Biji Teratai, hand sanitizer, dan antibakteri. 


\section{PENDAHULUAN}

Tumbuhan akuatik berperan sebagai agen rehabilitasi perairan . peran utama tumbuhan air adalah sebagai produsen utama, pemasok oksigen bahkan dapat menyerap logam berat. Tumbuhan air juga berfungsi sebagai biofilter yang menyerap kotoran dari urin ikan yang lambat laun bias berakibat racun untuk pertumbuhan ikan itu sendiri. Selain itu tumbuhan akuatik juga memiliki potensi lain di bidang industri pakan dan kesehatan yang dapat dikembangkan, yaitu sebagai sumber antibakteri. Salah satu tumbuhan akuatik yang dapat berperan sebagai sumber antibakteri adalah teratai atau lebih spesifiknya adalah biji teratai.

Biji teratai memiliki aktivitas antidiare secara in vitro [8]. Komponen fitokimia yang terdapat pada biji teratai adalah alkaloid, flavonoid, steroid, glikosida, saponin, tanin dan triterpenoid. Ekstrak etil asetat, merupakan ekstrak yang paling tinggi aktivitas antibakterinya dibandingkan ekstrak heksana dan etanol, mengandung alkaloid, glikosida, tanin, flavonoid, saponin dan triterpenoid [8]. Alkaloid berperan sebagai antibakteri dengan cara berinteraksi dengan dinding sel bakteri yang berujung pada kerusakan dinding sel dapat berikatan dengan DNA bakteri yang menyebabkan kegagalan sintesis protein [5]. Mekanisme kerja flavonoid sebagai antibakteri adalah membentuk senyawa kompleks dengan protein ekstraseluler dan terlarut sehingga dapat merusak membrane sel bakteri dan diikuti dengan keluarnya senyawa intraseluler [3][5][11]. Menurut Cushnie dan Lamb [6], selain berperan dalam inhibisi pada sintesis
DNA - RNA dengan interkalasi atau ikatan hidrogen dengan penumpukan basa asam nukleat, flavonoid juga berperan dalam menghambat metabolisme energi. Senyawa ini akan mengganggu metabolisme energi dengan cara yang mirip dengan menghambat sistem respirasi, karena dibutuhkan energi yang cukup untuk penyerapan aktif berbagai metabolit dan untuk biosintesis makromolekul. Ekstrak etil asetat biji teratai tersebut tidak menghambat pertumbuhan bakteri menguntungkan yaitu Lactobacillus sp. dan Bifidobacterium bifidum.

Pemakaian antiseptik tangan atau yang lebih dikenal dengan hand sanitizer aat ini telah dikenal luas di masyarakat kita. Selain itu pemakaiannya yang praktis dan nyaman membuat kita lebih memilih cara ini. Sediaan hand sanitizer yang beredar di pasaran dibuat dalam bentuk sediaan gel dengan zat aktif seperti etanol dan triklosan [10].

Hand sanitizer juga mengandung bahan antibakterial seperti triklosan atau agen antimikroba lain yang dapat menghambat pertumbuhan bakteri pada tangan seperti Escherichia coli dan Staphylococcus aureus [12]. Senyawa yang terkandung dalam hand sanitizer memiliki mekanisme kerja dengan cara mendenaturasi dan mengkoagulasi protein sel kuman [2].

Menurut hasil penelitian penelitian Rini [13] bahwa antiseptik pada beberapa merk dengan kadar alkohol $60-70 \%$ tanpa tambahan zat antibakteri lainnya memiliki sifat yang lebih polar, sehingga diameter daya hambat yang dihasilkan lebih besar pada bakteri Staphylococcus aureus. 
Jika antiseptik atau hand sanitizer digunakan secara terus menerus atau secara berlebihan dapat menyebabkan iritasi pada kulit bahkan menimbulkan rasa terbakar mengingat bahan dasar yang digunakan merupakan bahan kimia berupa alkohol dan triloksan.

Bahaya yang ditimbulkan oleh triklosan, menurut Cooney [4] menyebutkan bahwa triklosan akan merugikan kesehatan dalam jangka panjang. Selain membuat bakteri menjadi kebal, triklosan dapat mengganggu proses normal kerja hormon dengan berubah menjadi racun tiroid, selain itu triklosan memiliki sifat toksik seperti klorofenol yang dapat menyebabkan kanker. Triklosan beracun terhadap reproduksi dan perkembangan kesehatan. Triklosan juga dapat menyebabkan iritasi kulit dan gangguan endokrin [7].

Adanya dampak negative yang ditimbulkan dari triloksan dan alcohol menyebabkan meningkatnya keinginan masyarakat untuk kembali ke alam, maka dikembangkanlah sediaan dengan zat aktif dari bahan alam yang lebih aman (Hurria, 2014).

Gel dibuat dengan proses peleburan, atau diperlukan suatu proses khusus berkenaan dengan sifat mengembang dari gel. Carborner 940 akan mengembang jika ditaburkan dalam air, dengan adanya zat-zat alkali untuk membentuk suattu sediaan semipadat.

Pada penelitian ini akan mengkaji dengan tujuan dapat mengetahui efektivitas senyawa antibakteri sediaan gel hand sanitizer berbahan dasar ekstrak etil asetat biji teratai (Nymphaea pubescens) yang baik, efektif, stabil, dan aman dalam penggunaannya.

\section{METODE PENELITIAN}

\section{Bahan}

Biji Teratai dari jenis Nymphae pubescens. Air Suling, Etil Asetat, Gliserin, Trietanolamin Carbopol 940, Methyl Paraben, Medium Nutrien Agar, biakan murni (E. coli dan $S$. aureus.

\section{Alat}

Alat yang digunakan adalah alat gelas kimia, satu unit alat evaporator, neraca analitik, oven, pompa vakum, blender, $\mathrm{pH}$ meter, autoclave, laminarflow, petridish, pipet mikro, dan blue tip.

\section{Prosedur}

\section{Preparasi Biji Teratai}

Biji teratai dibersihkan dari pengotor menggunakan air kemudian dipotong dan dikeringkan. Setelah kering dilakukan penggilinga.

\section{Pembuatan Ekstrak Biji Teratai}

Biji teratai yang sudah digiling kemudian dimaserasi dengan etil asetat selama 3 hari. Pelarut diuapkan dengan rotavapor pada suhu $40^{\circ} \mathrm{C}$, dan kandungan pelarut etil asetat dihilangkan dengan menggunakan waterbath dengan menjaga suhunya $<60^{\circ} \mathrm{C}$. Ekstrak yang diperoleh digunakan sebagai sampel untuk analisis dan pengujian antibakteri

\section{Pembuatan gel hand sanitizer}

Sediaan gel dikerjakan dengan cara basis gel dikembangkan dengan ditaburkan carbonal 940 di atas air suling dalam gelas kimia . TEA dicampurkan kedalam basis yang telah dikembangkan lalu dihomogenkan. Ditambahkan ekstrak biji teratai, metil paraben dan gliserin lalu tambahkan ke 
dalam basis, setelah itu dihomogenkan sehingga terbentuk gel. Formulasi gel dilakukan pengulangan sebanyak tiga kali dengan konsentrasi $0,5 \%, 1 \%, 1,5 \%$.

Tabel 1. Formulasi sediaan gel hand sanitizer

\begin{tabular}{lllll}
\hline Bahan & \multicolumn{3}{l}{ Konsentrasi } & Fungsi \\
& $(\%)$ & & & \\
\cline { 2 - 5 } & F1 & F2 & F3 & \\
\hline Ekstrak & 0,5 & 1 & 1,5 & Zat Aktif \\
\hline Gliserin & 10 & 10 & 10 & Pengemuls \\
& & & & $i$ \\
\hline TEA & 1 & 1 & 1 & Enulsifier \\
\hline Air & 15 & 15 & 15 & Pelarut \\
Suling & & & & \\
\hline $\begin{array}{l}\text { Metilpar } \\
\text { aben }\end{array}$ & 0,2 & 0,2 & 0,2 & Pengawet \\
\hline $\begin{array}{l}\text { Carbop } \\
\text { ol 940 }\end{array}$ & 1 & 1 & 1 & Pengemba \\
\hline
\end{tabular}

\section{Uji Antibakteri}

Dibuat medium nutrient agar steril kemudian didinginkan hingga suhu $40-45^{\circ} \mathrm{C}$. Sebanyak $20 \mathrm{ml}$ medium nutrient agar yang telah bercampur dengan $0,02 \mathrm{ml}$ suspensi biakan bakteri dituangkan kedalam cawan petri. Dihomogenkan dan dibiarkan hingga memadat. Kemudian diletakkan blank disc ke dalam cawan petri yang berisi medium nutrient agar tadi, dimana blank disc tersebut terlebih dahulu dijenuhkan dengan sediaan gel yang mengandung ekstrak biji teratai (Nymphae pubescens) selama 15-30 menit. Kemudian cawan tersebut ditutup dan diinkubasi selama $1 \times 24$ jam pada suhu $37^{\circ}$ C, kemudian diukur diameter zona hambatannya.

\section{Uji Daya Sebar}

Penentuannya dilakukan dengan perlakuan sampel gel dengan beban tertentu diletakkan dipusat antara lempeng gelas, dimana lempeng sebelah atas dalam interval waktu tertentu dibebani anak timbangan diatasnya. Permukaan penyebaran yang dihasilkan dengan meningkatkan beban merupakan karakteristik daya sebar.

\section{Uji pH}

Pengukuran $\mathrm{pH}$ dilakukan dengan mencelupkan $\mathrm{pH}$ meter ke dalam sediaan gel yang telah dibuat .

\section{Uji Sineresis}

Setelah terbentuk gel, dilakukan pengamatan apakah terjadi sineresis sebelum dan sesudah diberi kondisi penyimpanan dipercepat yaitu pada suhu $5^{\circ} \mathrm{C}$ dan $35^{\circ} \mathrm{C}$ selama 12 jam sebanyak 10 siklus.

\section{HASIL DAN PEMBAHASAN}

\section{Uji Stabilitas Gel Hand Sanitizer}

Uji stabilitas gel hand sanitizer meliputi uji pH, uji sineresis, dan uji daya sebar.

1. $\mathrm{Uji} \mathrm{pH}$

Menurut ketentuan SNI No. 06-2588, nilai $\mathrm{pH}$ suatu sediaan dinyatakan baik pada nilai $\mathrm{pH}$ antara 4,5-6,5. $\mathrm{pH}$ sediaan gel hand sanitizer ekstrak biji teratai sebagai berikut :

Tabel 2. Hasil Uji pH

\begin{tabular}{ll}
\hline Sediaan & $\mathbf{p H}$ \\
\hline Formula 1 & 6,4 \\
\hline Formula 2 & 5,9 \\
\hline Formula 3 & 5,1 \\
\hline Kontrol & 6,5 \\
\hline
\end{tabular}


Berdasarkan hasil yang diperoleh dari uji $\mathrm{pH}$, sediaan gel hand sanitizer ekstrak bijji teratai pada formuasi 1 , formulasi 2 , dan formulasi 3 telah sesuai dengan ketentuan SNI No. 06-2588 dimana rentang $\mathrm{pH}$ antara 4,5-6,5 dan memenuhi persyarat untuk $\mathrm{pH}$ kuliT.

2. Uji Daya Sebar

Uji daya sebar bertujuan untuk mengetahui kemampuan sediaan gel hand sanitizer menyebar pada kulit. Penyebaran berkaitan dengan kemampuan sebaran senyawa aktif yang terkandung dalam gel pada kulit. Ekstrak biji teratai mengandung senyawa aktif alkaloid, glikosida, tanin, flavonoid, saponin dan triterpenoid [8]. Distribusi senyawa aktif perlu diperhatikan karena berkaitan dengan efektivitas dan efisiensi fungsinya. Hasil uji daya sebar sediaan gel hand sanitizer ekstrak biji teratai sebagai berikut :

Tabel 3. Uji Daya Sebar

\begin{tabular}{ll}
\hline Sediaan & Daya Sebar \\
\hline Formula 1 & $53 \mathrm{~mm}$ \\
\hline Formula 2 & $6 \mathrm{~mm}$ \\
\hline Formula 3 & $65 \mathrm{~mm}$ \\
\hline Kontrol & $45 \mathrm{~mm}$
\end{tabular}

Berdasarkan hasil uji daya sebar yang diperoleh, daya sebar sediaan gel hand sanitizer ekstrak biji teratai sesuai dengan standar SNI No. 06-2588 yang berlaku, dimana daya sebar yang baik memiliki nilai 50-70 mm, nilai ini dianggap sebagai kondisi semisolid yang nyaman dan stabil
3. Uji Sineresis

Sineresis adalah peristiwa keluarnya air dari dalam gel dimana gel mengkerut sehingga cenderung memeras air keluar dari dalam sel [9], akibatnya gel nampak lebih kecil dan padat.

Hasil uji sineresis sediaan gel hand sanitizer ekstrak biji teratai sebagai berikut :

Tabel 4. Uji Sineresis.

\begin{tabular}{ll}
\hline Sediaan & Uji Sineresis \\
\hline Formula 1 & Tidak Sineresis \\
\hline Formula 2 & Tidak Sineresis \\
\hline Formula 3 & Tidak Sineresis \\
\hline Kontrol & Tidak Sineresis
\end{tabular}

Hasil uji sineresis selama penyimpanan dipercepat menunjukkan bahwa sediaan gel hand sanitizer dengan variasi ekstrak biji teratai $0,5 \%$, $1 \%$ dan $1,5 \%$ tidak terjadi sineresis.

\section{Uji Organoleptis}

Uji organoleptis gel dilakukan dengan mengamati secara visual meliputi bentuk, warna dan bau dari gel. Hasil organoleptis teradap ketiga formula sediaan gel dengan variasi ekstrak biji teratai $0,5 \%, 1 \%$ dan $1,5 \%$ sebagai berikut :

Tabel 5. Uji Organoleptis.

\begin{tabular}{cccc}
\hline Organoleptis & F1 & F2 & F3 \\
\hline Warna & Hijau & Hijau & Hijau \\
& Muda & & $\begin{array}{c}\text { Tua } \\
\text { Bau }\end{array}$ \\
Herbal & Herbal & Herbal \\
\hline Bentuk & Semip & Semipa & Semipad \\
& adat & dat & at \\
\hline
\end{tabular}


Semua formula sediaan gel hand sanitizer ekstrak biji teratai homogen secara fisik. Hal ini menunjukkan bahwa bahanbahan dalam sediaan gel hand sanitizer ekstrak biji teratai terlarut dan bercampur sempurna.

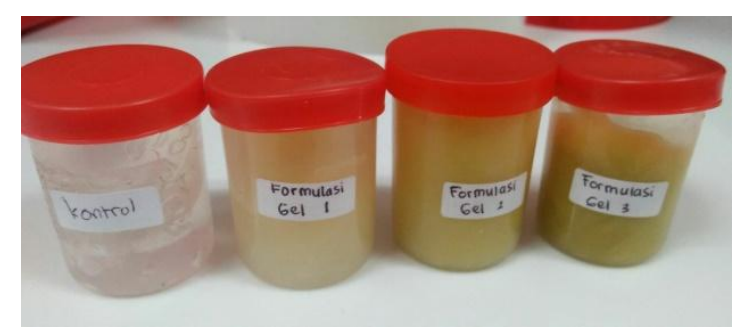

Gambar 1. Formulasi sediaan gel hand sanitizer ekstrak biji teratai.

\section{Uji Antibakteri}

Uji aktivitas antibakteri dilakukan untuk melihat potensi sediaan gel hand sanitizer ekstrak biji teratai dalam menghambat atau membunuh bakteri.

Zona hambat yang diperoleh dari hasil uji antibakteri sediaan gel hand sanitizer ekstrak biji teratai sebagai berikut :

Tabel 6. Uji Antibakteri terhadap Staphylococcus aureus dan Escherichia Coli.

\begin{tabular}{lll}
\hline Sediaan & \multicolumn{2}{l}{ Zona Hambat } \\
\cline { 2 - 3 } & $\begin{array}{l}\text { Escherichia } \\
\text { Coli. }\end{array}$ & $\begin{array}{l}\text { Staphylococcus } \\
\text { aureus }\end{array}$ \\
\hline Formula 1 & $7,25 \mathrm{~mm}$ & $6,75 \mathrm{~mm}$ \\
\hline Formula 2 & $8,75 \mathrm{~mm}$ & $8,5 \mathrm{~mm}$ \\
\hline Formula 3 & $10 \mathrm{~mm}$ & $12 \mathrm{~mm}$ \\
\hline Kontrol & $1 \mathrm{~mm}$ & $1 \mathrm{~mm}$ \\
\hline
\end{tabular}

Berdasarkan Tabel 6 pada uji sediaan gel hand sanitizer ekstrak biji teratai terhadap bakteri Escherichia coli dan Staphylococcus aureus bahwa pada sediaan gel dengan variasi ekstrak biji teratai sebesar 1,5\% memiliki zona hambat yang paing lebar daripada variasi esktrak $0,5 \%$ dan $1 \%$.

Berdasarkan klasifikasi respon daya hambat terhadap bakteri [1], zona hambat sediaan gel hand sanitizer ekstrak biji teratai terhadap bakteri Escherichia coli termasuk golongan sedang $(5-10 \mathrm{~mm})$. sedangkan terhadap bakteri Staphylococcus aureus termasuk golongan tinggi karena pada variasi ekstrak biji teratai $1,5 \%$ zona hambat yang dihasilkan sebesar $12 \mathrm{~mm}$. Semakin banyaknya jumlah ekstrak biji teratai yang ditambahkan menyebabkan meningkatnya kandungan senyawa aktif yang memiliki peran sebagai antibakteri sehingga aktivitas antibakteri akan semakin besar

\section{KESIMPULAN}

Berdasarkan penelitian yang dilakukan, maka dapat diambil kesimpulan bahwa :

1. Uji stabilitas sediaan gel hand sanitizer menunjukkan nilai $\mathrm{pH}$ sediaan gel hand sanitizer sesuai dengan $\mathrm{pH}$ kulit, tidak terjadi sineresis, dan daya sebar yang sesuai dengan standar SNI No. 06-2588.

2. Uji Organoleptis menunjukan bahwa semakin banyak ekstrak biji teratai yang ditambahkan, warna yang dihasilkan semakin gelap, aroma yang semakin kuat, bentuk yang semipadat.

3. Aktivitas antibakteri yang paling besar ditunjukkan pada sediaan gel hand sanitizer dengan variasi esktrak biji teratai sebesar $1,5 \%$ deengan zona hambat sebesar $12 \mathrm{~mm}$ terhadap Staphylococcus aureus dan sebesar $10 \mathrm{~mm}$ terhadap Escherichia coli. Aktivitas antibakteri semakin meningkat seiring semakin 
besarnya konsentrasi ekstrak biji teratai yang ditambahkan.

\section{UCAPAN TERIMAKASIH}

\begin{abstract}
Ucapan terima kasih disampaikan kepada pihak RISTEK DIKTI yang telah mendanai penelitian ini melalui PKM 2018 serta Universitas Negeri Surabaya yang telah memberikan fasilitas atas pelaksanaan penelitian kami dan untuk dosen serta laboran di jurusan kimia yang telah membimbing kami atas menuntaskan penelitian ini, sehingga terlaksana dengan baik, lancar dan sukses.
\end{abstract}

\section{DAFTAR PUSTAKA}

[1] Ardiansyah. Daun Beluntas sebagai Bahan Antibakteri dan Antioksidan. Tersedia di Berita IPTEK.com. 2004.

[2] Asngad, Aminah, Aprilia Bagas R, "Nopitasari. Kualitas Gel Pembersih Tangan (Handsanitizer) dari Ekstrak Batang Pisang dengan Penambahan Alkohol, Triklosan dan Gliserin yang Berbeda Dosisnya". Jurnal Bioeksperimen. Vol. 4 (2) Pp. 61-70, 2018.

[3] Bobbarala, V. Antimicrobial Agents. Intech, Croatia. 2012.

[4] Cooney, C.M., "Triclosan Comes under Scrutiny". Environmental Health Perspectiveive 118(6), A242, 2010.

[5] Cowan. "Plant Product as Antimicrobial Agents", Clinical Microbiology Reviews, Vol. 12, No. 4, Hal. 564-582. 1999.

[6] Cushnie, T.P.T., dan A.J. Lamb. "Antimicrobial Activity of Flavonoids". International Journal of Antimicrobial Agents. 26: 343 - 356. 2005.

[7] Dann, A.B., and Hontella, A., "oTriclosan: Enviromental Exposure, Toxicity and Mechanism of Action". Journal Applied Toxicology 31, 285-311. 2011.

[8] Fitrial $Y$, Astawan M, Soekarto ST, Wiryawan KG, Wresdiyati T dan Khairina R. "Potensi biji teratai sebagai antidiare". Jurnal Teknologi \& Industri Pangan 19(2): 158-164, 2008.

[9] Glicksman M. Food Hydrocolloids. Vol. II. CRC Press, Boca Raton; 1983.

[10] Hurria. "Formulasi, Uji Stabilitas Fisik, Dan Uji Aktifitas Sediaan Gel Hand Sanitizer Dari Air Perasan Jeruk Nipis (Citrus aurantifolia Swingle) Berbasis Karbomer". Jurnal Farmasi Fik Uinam. Vol.2 No (1) Hal : 28-33. 2014.

[11] Nuria, M.C., A. Faizatun., dan Sumantri. “Uji Antibakteri Ekstrak Etanol Daun Jarak Pagar ( Jatropha cuircas L) terhadap Bakteri Staphylococcus aureus ATCC 25923, Escherichia coli ATCC 25922, dan Salmonella typhi ATCC 1408". Jurnal IImu - ilmu Pertanian. 5: 26 - 37. 2009.

[12] Radji, Maksum dkk. "Uji Efektivitas Anti Mikroba Beberapa Merk Dagang Pembersih Tangan Antiseptik". Majalah IImu Kefarmasian. Vol. IV, No. 1. 2007; 1-6

[13] Rini, E. P., \& Nugraheni E. R. "Uji Daya Hambat Berbagai Merek Handsanitizer Gel Terhadap Pertumbuhan Bakteri Escherichia coli dan Staphylococcus aureus". Journal of Pharmaceutical Science and Clinical Research, 1(10), 18-26. 2018. 